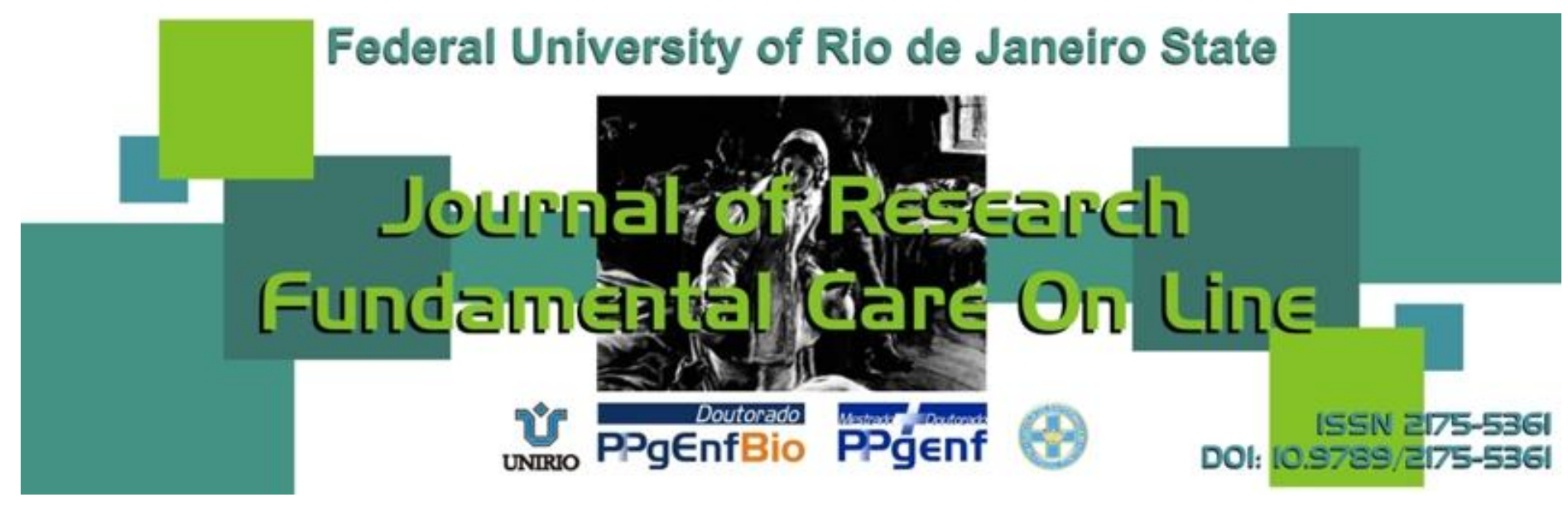

\title{
SYSTEMATIC REVIEW OF LITERATURE
}

WHO CARES FOR THE CAREGIVER: KEY FACTORS THAT AFFECT THE HEALTH OF NURSING PROFESSIONALS, A BIOPSYCHOSOCIAL VIEW

QUEM CUIDA DO CUIDA [DOR]: PRINCIPAIS FATORES QUE INTERFEREM NA SAÚDE DOS PROFISSIONAIS

DE ENFERMAGEM, UMA VISÃO BIOPSICOSSOCIAL

¿QUIÉN CUIDA AL CUIDADOR: LOS FACTORES CLAVE QUE AFECTAN LA SALUD DE LOS PROFESIONALES DE ENFERMERÍA, UNA VISIÓN BIOPSICOSOCIAL

Clecilene Gomes de Carvalho ${ }^{1}$, Sérgio Ricardo Magalhães²

\begin{abstract}
Objective: Biographical Survey in order to draw a parallel between the main factors that affect the health of nurses and the existing standards regulating (NR) include those factors. Method: Literature review, critical analysis and meticulous. Results: We need an institutional support that enables a human resources policy covering the worker's health in its totality, focusing on quality of life and care of workers in the biopsychosocial context. Conclusion: Among the main factors that affect worker health nursing are exposure to blood, excretions / secretions or body fluids, excessive overtime, postures in the development of work activities and still living with the pain. As the NR is important to note that although there is specific for health professionals, NR 32 complements and is complemented by the other NR. Descriptors: Occupational health, Occupational risks, Legislation, Nursing.
\end{abstract}

\section{RESUMO}

Objetivo: Levantamento biográfico a fim de traçar um paralelo entre os principais fatores que interferem na saúde dos profissionais de enfermagem e as normas regulamentadoras (NR) existentes que contemplam os referidos fatores. Método: Revisão bibliográfica, análise crítica e meticulosa. Resultados: É preciso um suporte institucional que possibilite uma política de recursos humanos que contemple a saúde do trabalhador em sua totalidade, enfocando a qualidade de vida e o cuidado dos trabalhadores no contexto biopsicossocial. Conclusão: Dentre os principais fatores que interferem na saúde do trabalhador de enfermagem encontram-se a exposição a sangue, excretas/secreções e ou fluidos corpóreos, horas extras excessivas, posturas inadequadas no desenvolvimento das atividades laborais e o continuo convívio com a dor. Quanto as NR é importante ressaltar que apesar de haver uma especifica para os profissionais da área de saúde, a NR 32 complementa e é complementada pelas demais NR. Descritores: Saúde do trabalhador, Riscos ocupacionais, Legislação de enfermagem.

\section{RESUMEN}

Objetivo: Estudio biográfico con el fin de trazar un paralelo entre los principales factores que afectan la salud de las enfermeras y del las normas regulatorias (NR) existentes incluyen aquellos factores. Método: Revisión de la literatura, el análisis crítico y minucioso. Resultados: Se necesita un apoyo institucional que permita una política de recursos humanos en materia de salud del trabajador en su totalidad, centrándose en la calidad de vida y cuidado de los trabajadores en el contexto biopsicosocial. Conclusión: Entre los principales factores que afectan a la enfermería profesional de la salud son la exposición a la sangre, excreciones / secreciones o fluidos corporales, exceso de horas extraordinarias, las posturas en el desarrollo de actividades de trabajo y todavía vive con el dolor. A medida que la NR es importante tener en cuenta que, aunque no es específica para los profesionales de la salud, la NR 32 complementa y se complementa con las otras NR. Descriptores: Salud laboral, Riesgos laborales, Legislación de enfermería.

${ }^{1}$ Graduated in Nursing by College 'Universidade do Vale do Rio Verde' (UNINCOR), campus Betim city. Member Association of Pulmonary Hypertension of the state Minas Gerais (AMIHAP). Post graduate in psychology multifocal. E-mail: clecilene@globo.com. Address: Street Upinduara, 220/302, New Eldorado district, Count (MG), zip code: 32340630 . Phone: (31) 86837327. ${ }^{2}$ Graduated in

J. res.: fundam. care. online 2013. jul./set. 5(3):122-131 
Mathematics, teaching of Nursing course of College 'Universidade do Vale do Rio Verde' (UNINCOR), campus Betim city. PhD in Biomedical Engeneering. E-mail: sergio.magalhães@unincor.edu.br.

\section{INTRODUCTION}

It's understood by Health Worker as a group of activities that is designated to, by other actions of sanitary and epidemiological surveillance, to promotion and health protection of the workers, as well as, to health recovering and rehab of the health of the workers undergone to the risks and the worsening that come from work conditions. ${ }^{1}$

The Federal Constitution from 1988, states that is competence of the Federal Government by the actions developed by Work Ministry, Social Securiy, attributions regulated in the Consolidation of Work Laws (Chapter V, title II, Law number 6.229/75), in the law number $8.212 / 91$ and $8.213 / 91$, that states about social security organization and cost plans and benefit plans of social security and in the Health Organic Law number $8080 / 900^{1-3}$

Among the competences of the Work Ministry is the elaboration of the standards regulating (NR) published in the ordinance 3.214/78 to establish technical and legal requirements about the minimum aspects of Occupational Health and Security (SSO). ${ }^{3}$

The worker's health, according to Unique Health System's attributions, it's in the Constitution, article 200 and in the Organic Health Law, articles 15 to 18 . The seventh article, XXII of the Constitution states as a worker's right the reduction of the risks at the job, by the edition of health, hygiene and security regulations. ${ }^{1-2}$

Law 8213/91, article 19 defines work accident that one that occurs in the exercise of the job for the company, or by the exercise of the job, provoking body injury, functional unsettle that causes death, loss or reduction, permanent or temporary of job capacity. ${ }^{3}$
Every year about 250 million workers are victim of the job accidents all over the world, besides that, 160 million new cases of occupational disease provoked by factors related to the job environment are diagnosed. ${ }^{4}$

In Brazil, official data settled that health sector is the first in number of job accidents registered with 23.108 notifications in 2003. It's over than high risk areas like construction. In 2004, a total of 458.956 accidents were notified, 30.161 of these corresponded to health sector. ${ }^{5}$

According to World Work Organization, most of the job accidents could be prevented, if he regulations related to it would be respected. ${ }^{6}$

From a biopsychosocial view and the contextualization that permit a holistic look of the person and of the disease that cover the physical, psychological and social ${ }^{7}$ dimensions and because of the fact to exist a constitutional guarantee, laws and NR that drive to a accident prevention, it was questioned why these scaring data, what started a carrying out of a revision bibliographic research, in order to make a parallel between the main factors that interfere in the health of the nursing professionals and the existing NR that consider those factors. The aim of this study is to sport the importance to obey the law and the necessity to aware the prevention among the health professionals as fundamental to keep the health, because to care someone else is, at first, to care to yourself.

\section{METHODOLOGY}

After the choice of the theme question and of the uniterms, it was carried out a bibliographic revision qualitative study. For that, it was uses a bibliographic study in the magazines of the data base of the La Literatura Latino Americana and

J. res.: fundam. care. online 2013. jul./set. 5(3):122-131 
Carvalho CG, Magalhães SR.

from Caribe in Health Sciences (LILACS), Scientific Electronic library online (Scielo), national Library of Medicine (Medline), and from the Latin American and Caribean Center of Information in Health Sciences (BIREME) on Internet. The selected uniterms to the referential search were: NR's, ergonomic, quality of life, stress, occupancy diseases, mental health, worker's health, biopsychosocial, using as a basis the nursing worker's health sector. The uniterms combination was used as a strategy to search in the basis, in order to make the search easy to construct the theorical fundamental of the research from solid knowlegment. 61 articles were held, at first, all of them were read, identified their subject matter and their sense cores.

At the first moment, we seek for articles that focused the factors and the NR's, but those articles just mentioned two NR's. So, we read all NR's to fill the referential.

It was excluded the articles that didn't offer subsidies to the theme under study, or weren't into the research object.

\section{RESULTS AND DISCUSSION}

After the reading of the articles, we noted, despite emphasizing the nursing workers environment, that every worker is subject to suffer some kind of job accident. Of course, it depends on the kind of job and the environment.

The ordinance 3214 of June $8^{\text {th }}, 1978$ approved the regulations (NR'S) related to Work security and medicine, that must be obeyed for private and public companies, public and governamental organizations that have workers governed by the consolidation labor laws (CLT). The objective of the NR's is to show up the determinations in the articles 154 to 201 of the CLT, created and extended to reduce or eliminate the risks in the labor environment, to become it

J. res.: fundam. care. online 2013. jul./set. 5(3):122-131
Who cares for the caregiver...

the safest possible. The NR 5states the Internal Commission for Accident Prevention (CIPA) and has the objective to prevent diseases and labor accidents to make compatible permanently work, life preservation and the promotion of the workers health. ${ }^{8}$

Even according to the cited source, the NR 9 was created aiming life preservation, worker's integrity, by the anticipation, recognition, evaluation, control of the existing risks or to exist in the future, considering the environmental and natural resources protection, according the program of prevention of environmental risks (PPRA). The other NR's contributed to the labor process, modifying and acting in the adaptations and job conditions and the psychophysiological (ergonomics) characteristics, cited in NR 17.

Nursing professional is the health professional that is the most exposed to the risks in the health sector because nursing is the biggest individualized group of health workers; non-stop assistance, 24 hours a day, does $60 \%$ of the actions in health, and it is the category that comes into physical contact with patients. In Brazil there are more than one million of workers in health. They are nurses, technical and auxiliary in nursing subject to labor conditions capable to treat the surviving of the profession. ${ }^{5}$

In November $16^{\text {th }}$, 2005 is published NR 32 (Safety and Health in Health facilities), that states basic directions to implant protection measures related to safety and worker's health, as well as of those who work promoting and assisting health in general. ${ }^{8}$

NR 32 is considered very important in the Brazilian scenario as a specific federal legislation that approaches questions on safety and health labor, in health sector; the existing regulations are spread in many NR's and resolutions that weren't formed focusing on health. It is believed that beneficial changes could be reached by the 
Carvalho CG, Magalhães SR.

aforementioned regulation, since proceedings and protective measures will be undertaken in order to promote labor safety and accidents and occupancy diseases prevention. ${ }^{9}$

The personal exposition of the nursing workers to the biological risk is bigger due to their close and frequent contact with the infected patients. ${ }^{5}$

Many times, the face (eyes, mouth and nose) to the reach of drops of blood and other body fluids, during proceedings, coughs, sneezes, vomit, saliva, blood and pus are observed and controlled before the rejection; recipients are washed and disinfected, sterilized; pajamas, shirts and linens are changed. And all of these are made by the nursing worker. Health sector was the first to occur HIV occupancy transmition and, in this sector, nurses became the main group in risk. Hepatitis type $B$ is the most frequent occupancy disease among people who work in hospitals. Comparing to the population in general, the risk to take hepatitis tiype $B$ is 11 times higher than in people who work in laboratories and nursing. In hospital taken as a reference to AIDS treatment in Minas Gerais, it was found $16 \%$ of the employees infected by tuberculosis bacteria. Accidents caused by needles are responsible for $80 \%$ to $90 \%$ of transmissions of infectious diseases among health workers. These numbers prove how fragile are the health workers in front of the accidents and occupancy diseases. ${ }^{5}$

In order to avoid the risk to expose to biological material, every professional must have Personal Protection Equipment (EPI), whose purpose is to neutralize the action of potential accidents that can cause injuries to the worker and protect him/her against probable health damages. NR6 regulate the use of EPI and the company must give to the workers for free. (CLT article 166, item 6.3 subtime A - article 167, item
Who cares for the caregiver...

6.2). But the workers must demand these equipments and use them correctly. ${ }^{8}$

Even as preventive measure, every health worker must receive for free, active immunization against tetanus, diphtheria, hepatitis B and Control Program established in the Occupational Health Medical - PCMSO (NR 7). It is important to remember that preventive immunization doesn't rule out the care in doing the activities.

In relation to the physical risks, in NR 32, only ionizing radiations are detailed: radiation, medical and dental radiology, brachytherapy and waste. In fact, it is a more dangerous risk because is not possible to be detected by the senses: it doesn't have smell, or any sound, can't be seen or touched. The environmental factors (noise, lightning, thermal comfort and clean conditions) are in the general provisions in the NR. It doesn't mean that they are not important, because risk factors can contribute to the development of occupational diseases. ${ }^{8}$

About chemical risks, NR 32 approach protection measures against the effect of the medical toxic gases, medicines and drugs of risk, antineoplastic drugs, gases and anesthetic gases. To prevent and control chemical risks, NR 32 reminds the necessity to obey what is established in these ordinances: NR 07 - Medical Health and Occupational Program of Control; NR 09 Prevention of Environmental Risks Program; NR 15 - Unhealthy activities and operations; NR 26 Signs of Safety, Interministerial Ordinance MS/MTE 482 of April $16^{\text {th }}, 1999 .^{5,8}$

The monitoring of the compliance of the NR's in every labor environment - private or public, formal or informal, must be carried out by the sanitary surveillance agents in the states and cities, but it doesn't exempt the professional to be responsible for their own health, adopting a safety behavior, that they have learnt during the

J. res.: fundam. care. online 2013. jul./set. 5(3):122-131 
Carvalho CG, Magalhães SR.

graduation, extended education, qualified supervision, labor organization, material resources (including EPI's), selection of prepared professionals to take care of people who have infectious diseases, beyond well explained rules about barriers and isolation. Education and serum control and immunization make part of the program destined to the risk group, represented for workers exposed to the contact with blood, its derivates and other body fluids. However, the safe regulations don't work if the material wouldn't be used correctly, if the professionals ignore its use or if the lacks of organization block its application up.

The labor environment, under bad physical, mechanical and psychological conditions, is considered one of the main risk factors to develop alterations in the muscleskeletal system. The continuing and long body exposition to the risk factors favors the emerge of occupational diseases. ${ }^{10}$ NR 17 seek to establish parameters that permit the work conditions adaptation to the workers' psychophysiological characteristics (ergonomics), in order to provide maximum comfort, safety and efficiency. The labor conditions include aspects related to rising, transport and discharge of materials, to the furniture, equipment, work environmental conditions and the job itself. ${ }^{8}$

Among the most frequent diseases related to work are Repetetive Effort Injuries/Musculoskeletal Disorder related to the job (LER/DORT). ${ }^{10}$

In the occupations in the Health sector, nursing, in particular, has been specially affected by the musculoskeletal disorder.

The terminology LER/DORT characterize functional, mechanical disorders and injuries of the muscles and or tendons and or fascia or nerves and or articulation and bone ends of superior members caused by biomechanically J. res.: fundam. care. online 2013. jul./set. 5(3):122-131
Who cares for the caregiver...

incorrect use of those members, that result in pain, fatigue, reduced performance at work, temporary incapacity and, depending on the case, may develop a chronic pain syndrome, in this phase aggravated by psychological factors (related to job or not) capable to reduce the sensibility limits of the individual. ${ }^{11}$

Among the main risk factors related to musculoskeletical disorders are: labor organization (increasing on working hours, excessive over time, fast pace, workers deficit); environmental factors (inadequate furniture, insufficient lightning) and probable overcharging in some body segments depending on the movement, for instance: excessive force to do some tasks, repetition of movements and inadequate posture on developing labor activities. ${ }^{10}$ These risk factors, added to the lack of time for leisure, drives the nurses to develop occupational stress. When the job is carried out under unhealthy and unsafe conditions, like chemical, physical and biological risk contact, ergonomics and accidents, may affect the physical and psychological well-being of the individual. ${ }^{12}$

Therefore, it's important to highlight that the risk factors are not only related to the environment, it's also important to highlight that there are external and internal variables that affect the life and well-being of the people. Those act independently and should be considered in the daily nursing care, because affect equally health and disease. Among external variables, it is spotted physical security and environmental factors; and internally are the cultural, mental and spiritual activities. ${ }^{13}$

The work means a double relationship between men and nature that generates meaning. It's by the job that the act to give meaning to the nature is realized. On the other hand, the breaking on the meanings circuit from the 
Carvalho CG, Magalhães SR.

worker's point of view causes suffering that may impair the mental health. ${ }^{14}$

The human beings live in an environment conductive to alterations and changes that many times are viewed as challenging or threatening or hazard to the dynamic equilibrium that drives to the state of stress. The level of impairment depends on how each person adapts to the environmental changes. The adaptation consists on how the person is going to face the problem, requiring a changing in the organizational structure of the individual. ${ }^{7}$

New business settings are demanding, in different level and among different productive sectors, new requirements on doing the tasks. Among the requirements are more qualification and more competence acquisition by the workers. Those demanding focus particularly in the service sector, because of its peculiarities, how the direct relationship between the worker and the client or user and the diversity of information.

Besides that, the services of health care grab specifications related to treat pain, suffering, to organic, emotional and social badbeing of the people. However, requires from the professionals and additional charge of interpersonal skills, beyond inherent conditions of professional exercise that include shift work scales and strong external pressure. ${ }^{15}$

When is not possible to reorganize the job by the worker, occurs blocking of psych apparel, accumulating puncional energy, and when the worker doesn't discharge it working, occur dissatisfaction, fatigue, tension, suffering. When there is a relational flexibilization of the man with the company, this allows the employee to full use of his psychomotor, psychosensorial and psychological skills, enabling to reach pleasure on working and in this way, an exhausting task could be realized in balanced way. ${ }^{16}$

J. res.: fundam. care. online 2013. jul./set. 5(3):122-131
Who cares for the caregiver...

The author above distinguishes two types of suffering: pathogenic and creative. This happen when all transformation possibilities, improvement and management in the way to organize the job have ever been tried. The pathogenic suffering happens when all possibilities of the individual are exhausted. The overcharging in the companies lead the workers to an energetic wear that ends in feeling of tension and lack of stimuli to do the job.

The interpersonal relationships in the health team are referred by many professionals as a contributing factor to stress, a group of body reactions to physical, psychological, infectious attacks and other, capable to disturb homeostasis, that comes from the environment where people develop their labor activities as well as the pace and the services demands, because the problem of an individual be or not to be stressed, is the result on adding the influence of the system and how an individual face the demands of the environment, so the way of life and the activity of a person contribute to determine his/her health and disease. ${ }^{17}$

The symptoms of stress vary from person to person. The physical symptoms may be more evident in some people, who may have excessive reactions or weight loss, irregular sleeping or develop bad breathing problems, in other people mental sadness is dominant, causing depression and extroversion. They start to neglect the family, don't show a good work performance and mood swings and behavior. ${ }^{7}$

We must differentiate psychological stress from the occupational stress, because the determining factor is important to characterize them.

The psychological stress is distinguished by a relation between the person and the environment, where that person feels overcharged, by a chronically emotional tension 
Carvalho CG, Magalhães SR.

and his/her resources are exceeded threatening his/her well-being with consequent reducing of the personal and professional fulfill. Besides that, can generate diseases and appear in other ways like absenteeism, turn-over, delays, dissatisfaction, sabotage and low production. ${ }^{18}$

The occupational stress involves negative attitudes related to the users, customers, company and the job, so it is an important factor to be understood, since nursing is characterized as stressful because the intense emotional charge that comes from the relation patient-nurse. It's worth to remember that environmental factors like physical space, ergonomics, psychological pressure, lack of equipment and medicines, occupational activity, ease very much the arising of the occupational stress, factor that may affect the attendance quality job. ${ }^{19}$

An example of the interaction of these two types of stress is the Burnout syndrome defined as a process that is developed when job environmental characteristic and personal characteristic are mixed. This is a problem that affects service professionals, mainly those ones who take care of the others, when the service often occurs in situations of emotional shifting. The exercise of these professions is full of ambiguities, like deal with the tiny distinction between professional and personal involvement helping the other. The syndrome also assumes a multidimensional conception that is characterized by emotional weakening, reducing on the personal satisfaction in the job and depersonalization of the other. The first one is referred to fatigue feeling and reducing of the emotional resources needed to deal with the stressful situation. The second one is referred to the perception of deterioration of the self competence and lack of satisfaction with the fulfillment and the job success. The third component refers to negative

J. res.: fundam. care. online 2013. jul./set. 5(3):122-131
Who cares for the caregiver...

attitudes, skepticism, and insensitiveness and not worries to the people. ${ }^{20}$

These experiences added to the excitement of life lead the caregiver to seek defense mechanisms or facing to support the internal mobilization on which he or she is submitted, what means a lack of interest to the other, mechanic acting, not perception to the other as a human being, in the way that are structured nowadays, don't ease the care of the caregivers, they are places that mobilize stress, feelings and emotions. ${ }^{13}$

The fact to live in a capitalistic world, where the subject is valued by his/her financial rise, i.e., material acquisitions and status will include him/her in this society, leads the seek for capital saving overcome the necessity to have quality of life. Nursing as a profession is not different, and nurses suffer interference from this society.

The frenetic lifestyle and often monetary needs and maintaining a social status, causing the worker set himself a tough pace of activities involving the employment relationships and domestic life, thus providing stress. ${ }^{17}$

In a world of hard work and lack of time for leisure and to take care of themselves. Leisure a medium that should be used to confront the contradictions of the routine of life, a way to take care of themselves to meet the essential possibilities to care for others.

Leisure is an occupation is not compulsory, free choice of the individual who lives and whose values provide recovery psychosomatic conditions and personal and social development. ${ }^{13}$

The history of human caring and history of nursing as a science has an important link. Nevertheless the focus on attention always has been on to take care of the other, the patient, but never on caring for the caregiver. The self-care is of highlighted importance, especially in an area 
Carvalho CG, Magalhães SR.

which requires a professional routine loaded with high degree of tensions that involves the entire team, such as health. Many people moving and chatting constant complain anxiety, sadness, pain, death and long working hours are the most routine of these professionals and, in particular, the nurse. ${ }^{21}$

Thus, leisure in all professions, is fundamental and in the case of an occupation that gather "taking care" of another becomes essential for this care is drove in a humane way.

It should be noted that diseases relate to work injuries are predictable and therefore preventable. You need an institutional support that enables a human resources policy that addresses worker health as a whole, focusing on the quality of life and care of the caregivers in the existential context and in the workplace. Health institutions and service managers need to open spaces for workers to exercise the practice of self care and recognize its importance in health. ${ }^{13}$

In recognition of professionals who need to care for self-care in order to search an biopsychosocial equilibrium is imperative that they know the laws and NR's governing their job so that they can thus collect the effectiveness of their implementation.

NR 32 is a great achievement for professionals in health, but their existence can't remain just on paper. It is so important that all professionals in this sector are informed about this regulation, and claim appropriate working conditions, exercising their role as workers and citizens who fulfill their tasks and reaffirm their rights, especially that of working safely. ${ }^{9}$

Note that care to take a breadth which extends only to the workforce after studies, it is needed to plant the seed, yet, in academia, in order to prepare professionals for them to able to identify and recognize which factor in their work, which interfere with their health. And prepare you J. res.: fundam. care. online 2013. jul./set. 5(3):122-131
Who cares for the caregiver...

to be able to use strategies to keep their health, and prepare you to be capable to manage strategies to maintain their health.

Health professionals should recognize that part of the process, as protagonists. Discussions and studies about the meaning of care, need to be worked during the training of nurses, in order to understand care as a process that has an important dimension and complex both in the experience of someone who care about who takes care, or even to take care of those ones who teach and those are learning. ${ }^{21}$

Care for the caregiver nursing is the responsibility of Federal Government, states and municipalities, but this does not exclude the task caregiver's own self-care institutions and not taking care of professionally.

It is needed for workers, including all employees are aware that they are responsible for their safety and depends on them to demand from institutions and secure decent work.

It is hoped that this study contributes to the importance of effective actions and preventive education for workers in this group and serves an input to discussions and reflections of students in graduation, health workers and managers, for educating and caring is, also possible who cares for a more humanized.

\section{CONCLUSION}

It is noted that all the items related to the job environment in nursing are unanimous in recognizing it as a stress and susceptible to accidents. This makes it necessary to exercise caustion and comply with all standards regarding the performance of duties.

Among the principal factors cited in the bibliography, which interfere with occupational health nursing are: exposition to blood (fecal or body fluids and secretions), the organization of 
work (raising working hours, excess of overtime, rapid pace, shortage of workers, work during the night), environmental factors (inadequate furniture, low lightning) and the possible overload of body segments in certain movements and postures in the development of labor activities. In continuous tract with pain suffering and organic, emotional and social malaise people.

NR 17 is related to ergonomics is to establish parameters for the adjustment of working conditions to the psychophysiological characteristics of workers in order to provide maximum comfort, safety and efficient performance. However, it is not clear in regard to the risks arising from mental fatigue, which nursing professionals are subject.

NR 32 states pretty well when it comes to basic measures to prevent accidents resulting from biological, chemical and physical. However, it is deficient in relation to psychosocial and ergonomic injuries. Therefore it is important to note that although there is a specific NR for workers in the health area, this does not relieve companies and workers from get together with existing guides in other NR. NR 32 from the complements and is complemented by other NR.

\section{REFERENCES}

1 - Brazil. Law No. 8080. (09.19.1990, art 6, § 3). Brasilia in 1990. [Accessed on June 1, 2011]. Available

http://portal.saude.gov.br/portal/arquivos/pdf/le i8080.pdf.

2 - Brazil. Federal Constitution of Brazil in 1988. [Accessed on June 1, 2011].Available at: http://www.planalto.gov.br/ccivil_03/constituica o/constitui\% C3\% A7ao.htm.

3 - Brazil. National Policy on Safety and Occupational Health. Brasilia, 2004. [Accessed on May 4, 2011]. Available at: http: / / www.previdenciasocial.gov.br/arquivos/off ice/3_081014-105206-701.pdf.

4 - Santos, Ana CP, New Towns, Monica M, Paizante, Grasiella O. Accidents At Work And Biosafety Hospital Environment. Rev. Edu., Mid Amb. and Health [online] 2008; 3 (1) :51-62. J. res.: fundam. care. online 2013. jul./set. 5(3):122-131
[Accessed on 10 May 2011] Available from: http://www.faculdadedofuturo.edu.br/revista/20 08/pdfs/REMAS3 (1) 51a62.pdf.

5-Brazilian Association of Nursing - ABEN. Primer of professional nursing: health, safety and good job conditions. ABEN, Rio de Janeiro, 2006. [Accessed on 14 April 2011]. Available at: http://www.abennacional.org.br/download/cartil ha.pdf.

6 - Revises Protection - protection Brazilian Yearbook 2010. Data globasi:

Profile of the world accidentality exclude Brazil from the updated statistics of the ILO. [Accessed on 28 April 2011]. Available at: http: / /www. protecao.com.br/site/content/mater ias/materia_detalhe.php?id=JyyJAc.

7 - LAS Baptist, HM Guedes. Occupational Stress and Nursing: Approach In Unit From The Mental Health Care. UNILEST, Minas Gerais, 2006. [Accessed on 14 March 2011]. Available at: http://www.unilestemg.br/revistaonline/volumes /02/downloads/artigo_17.pdf.

8 - Brazil. Regulatory standards - Portal of work and employment. Brasilia, 2010. [Accessed on 28 April 2011]. Available at: http: / / www.mte.gov.br/legislacao/normas_regula mentadoras/default.asp.

9 - Robazzi MLCC, Marziale MHP. The standard 32 and its regulatory implications for nursing staff. Rev. Latino-Am. Nursing, Ribeirao Preto, [online] v. 12, n. 5, Oct. 2004. [Accessed on June 1, 2011]. Available at: http: / /www.scielo.br/scielo.php?script=sci_arttex tetpid=S0104-

$11692004000500019 \&$ lng=en\&nrm=iso.

10 - Magnago TSBs, Lisbon MTL, Souza ER, MC Moreira. Musculoskeletal disorders in nursing personnel: association with working conditions. Rev. bras.Nurse., Brasilia, [online] v. 60, n. 6, Dec. 2007. [Accessed on June 1, 2011].Available at: http: / /www.scielo.br/scielo.php?script=sci_arttex tepid=S0034-

$71672007000600015 \& \operatorname{lng}=e n \& n r m=i s o$.

11 - Mello CD. Occupational diseases with emphasis on the RSI / WMSD [monograph]. Florianópolis: Specialization in University Management (PROGEU), Federal University de Santa Catarina, 2003. [Accessed on May 1, 2011]. Available at: http://www.grucad.ufsc.br/celly/tcc_celly.pdf. 12 - Magellan AP, Castro NMS. Determinants of stress in nurses working in intensive care unit (ICU), intensive care unit (ICU) and emergency room. St. Camillus School - MG - 2007/2008. [Accessed on May 6, 2011]. Available at:

13 - Gomes CM. Dumazedier and leisure studies in Brazil: a short historical background. UFSJ, Rio de Janeiro, 2004. [Accessed on May 1, 2011]. Available at:

14 - SR Tolfo, Piccinini V. Meanings of work: exploring concepts, variables and empirical 
studies in Brazil. Psicol. Soc, UFSC, Porto Alegre, [online] v. 19, no. spe, 2007. [Accessed on June 1, 2011]. Available at: <http://www.scielo.br/scielo.php?script=sci_artte xt\&pid $=$ S0102-

$71822007000400007 \& \operatorname{lng}=e n \& n r m=i s o>$.

15 - LO Borges, Argolo JCT, Baker MCS. Organizational values and Burnout Syndrome: two moments in a public hospital. Psicol. Reflex. Crit., UFRN, Porto Alegre, [online] v. 19, no. 1, 2006. [Accessed on 15 May 2011]. Available at: <http:/ / www.scielo.br/scielo.php?script=sci_artte xt\&pid=S0102-

$79722006000100006 \&$ lng=pt\&nrm=iso $>$.

16 - Dejours C Abdoucheli, E. Desire or motivation? The question the psychoanalytic work. In: DEJOURS, C.; ABDOUCHELI, E. JAYET \& C.Psychodynamics of work: contributions to the school dejourian analysis of the pleasure, pain and work. London: Atlas, 1994.

17 - Silva JLL, Melo ECP. Stress and implications for nursing workers. Health Promotion, UFF, Rio de Janeiro, [online] v.2, n.2.p.16-18. 2006. [Accessed on 16 May 2011]. Available at: http://www.uff.br/promocaodasaude/estr.trab.pd f.

18 - Ferreira JM. Health at Work: Basic Themes for the professional caregiver health workers - 357p. Roca: New York, 2000.

19 - Guimarães, Liliana A Grubits, Sandra (Eds.). Series mental health and work.New York: Psychologist, 1999. v.1, p.276.

20 - LO Borges, Argolo JTC, ALS Pereira, Machado EAP, Smith WS. The burnout and organizational values: a comparative studies in university hospitals. Psicol.Reflex. Crit., UFRN, Porto Alegre, [online] v. 15, n. 1, 2002. [Accessed on May 5, 2011]. Available at: http://www.scielo.br/scielo.php?script=sci_arttex t\&pid=S0102-

$79722002000100020 \&$ lng=pt\&nrm=iso.

21 - Ladies KCA, Munari DB, Smith KM - Caring for the Caregiver: reflections on learning this skill. Electronic Journal of Nursing, UFG, Goias, vol. 06, n.02, p. 272-278, 2004. [Accessed on May 1, 2011]. Available at: http://www.fen.ufg.br/revista/revista6_2/pdf/R1 _cuidador.pdf.

\section{Received on: 13/06/2011}

\section{Reviews required: 27/06/2011}

Approved on: 08/07/2011

Published on: 01/07/2013

J. res.: fundam. care. online 2013. jul./set. 5(3):122-131 